\title{
The Effect of Government Expenditure and Economic Growth on Gender Development Index in Special Region of Yogyakarta Province
}

\author{
By \\ Silvina Esta Nurwanti ${ }^{\left.1^{*}\right)}$, Nunik Kadarwati ${ }^{11}$, Supadi ${ }^{11}$, Khalid Eltayeb Elfaki Adam ${ }^{2)}$ \\ 1) Faculty of Economic and Business, Jenderal Soedirman University \\ ${ }^{2)}$ Faculty of Commercial Studies, University of Gezira, Sudan \\ ${ }^{*}$ Corresponding Author: silvinaesta7386@gmail.com
}

Submission: March 09, 2021; Accepted: June 16, 2021

\begin{abstract}
The phenomenon of the development inequality between men and women is development problems that still occur in many regions and can be measured using gender development index. This research has purpose to analyze the factors that influence on gender development index in Special Region of Yogyakarta and indentifying variables that has most influence on gender development index in Special Region of Yogyakarta. This research uses gender development index as dependent variable and was implemented in the Province of D.I. Yogyakarta, in contrast to the previous research that already exists. In this research, the author have a hypothesis formulation that all independent variables, government expenditure in education sector, government expenditure in health sector and economic growth has a positive effect on gender development index. This research uses a panel data regression analysis with fixed effect model (FEM) approach. The results of this research indicate that variable of government expenditures in education has a negative and significant effect on gender development index in Province of D.I. Yogyakarta, the variable of government expenditures in health and variable of economic growth has a positive and significant effect on gender development index in Province D.I. Yogyakarta, and the dependent variable has most influence on gender development index in Special Region of Yogyakarta is a government expenditure on health. The implication of this research is the government to pay more attention to ability of each region in realizing the education expenditure, it is neccesary to strengthen cooperaton and equalize of mission both at the province and district/city level to optimize government performance, and need equality on education to reduce education gap in Special Region of Yogyakarta. For expenditure in the health sector, government should increase the percentage of budget allocation for health sector with provision minimum of 10 percent from local government revenue and expenditure budget (APBD) and need performance optimization in financial management so that health budget can be realized optimally as well. Meanwhile in economic growth, the government should to make equalize in the economic growth for each district or city so that can be enjoyed by all level of society. The limitations of this study are use of research data with a limited period and limited information on availability of information on each research variable used.
\end{abstract}

Keywords: Gender Development Indeks, Government Expenditures In The Education Sector, Government Expenditures In The Health Sector, Economic Growth

\section{ABSTRAK}

Fenomena ketimpangan pembangunan antara laki-laki dan perempuan merupakan permasalahan dalam pembangunan yang masih terjadi di banyak daerah, yang dapat diukur menggunakan indeks pembangunan gender. Penelitian ini bertujuan untuk 
menganalisis faktor-faktor yang mempengaruhi indeks pembangunan gender di Provinsi D.I. Yogyakarta dan variabel manakah yang pengaruhnya paling besar terhadap indeks pembangunan gender. Dalam penelitian ini, peneliti menggunakan variabel indeks pembangunan gender sebagai variabel dependen dan dilakukan di Provinsi D.I. Yogyakarta, berbeda dengan penelitian terdahulu yang sudah ada. Dalam penelitian ini peneliti merumuskan hipotesis adalah semua variabel bebas yaitu pengeluaran pemerintah bidang pendidikan, pengeluaran pemerintah bidang kesehatan dan pertumbuhan ekonomi berpengaruh positif terhadap indeks pembangunan gender. Penelitian ini menggunakan alat analisis regresi data panel dengan pendekatan model efek tetap (FEM). Hasil penelitian ini menunjukkan bahwa variabel pengeluaran pemerintah bidang pendidikan berpengaruh negatif dan signifikan terhadap Indeks Pembangunan Gender di Provinsi D.I Yogyakarta, variabel pengeluaran pemerintah bidang kesehatan dan variabel pertumbuhan ekonomi berpengaruh positif dan signifikan terhadap Indeks Pembangunan Gender di Provinsi D.I Yogyakarta, dan variabel bebas yang paling besar pengaruhnya terhadap Indeks Pembangunan Gender D.I. Yogyakarta adalah variabel pengeluaran pemerintah bidang kesehatan. Implikasi dari penelitian ini adalah pemerintah untuk lebih memperhatikan kemampuan tiap daerahnya dalam merealisasikan anggaran pendidikan, perlu adanya penguatan kerja sama dan penyelarasan misi baik dalam tingkat provinsi maupun tingkat kabupaten/kota untuk mengoptimalkan kinerja pemerintahan, serta diperlukan pemerataan pendidikan untuk mengurangi kesenjangan pendidikan yang terjadi di D.l. Yogyakarta. Untuk pengeluaran bidang kesehatan, pemerintah hendaknya meningkatkan persentase alokasi anggaran untuk bidang kesehatan dengan ketentuan yang ada yaitu minimal 10 persen dari anggaran pendapatan dan belanja daerah (APBD) serta perlu adanya pengoptimalan kinerja dalam pengelolahan keuangan agar anggaran kesehatan yang dapat direalisasikan secara optimal juga. Sedangkan pada pertumbuhan ekonomi, pemerintah hendaknya melakukan upaya pemerataan dalam pertumbuhan ekonomi tiap daerah kabupaten/kota agar hasilnya dapat dinikmati seluruh lapisan masyarakat. Keterbatasan dalam penelitian ini adalah penggunaan data penelitian yang terbatas periodenya dan terbatasnya ketersediaan informasi mengenai setiap variabel penelitian yang digunakan.

Kata Kunci: Indeks Pembangunan Gender, Pengeluaran Pemerintah Bidang Pendidikan, Pengeluaran Pemerintah Bidang Kesehatan, Pertumbuhan Ekonomi

\section{INTORDUCTION}

A country can be called developed countries if the development can reach all aspects of every sector in country. The successfull country's development can not only seen from high level of economic growth, but also from quality of human resources. Human development is also directed at promoting the quality of human resources without distinguishing of genders, so that better life can be realized. In human development, gender differences are often discussed, where focus on how to achieve gender equality to improve the quality of human resources without differentiating between men and women. The World Bank considered the gender equality as a key to achieve development goals, because gender equality will strengthen the country's ability to grow and develop, reduce poverty and effective governance (World Bank, 2001). Gender equality means same condition for men and women to get opportunities and rights as a human, in order to be able play a role and participate in political, economic, socio-cultural, defense and equality in enjoying the results of development (KPPPA, 2015).

Gender equality can be measured using Gender Development Index which is formulated as the ratio of Human Development Index for Women and for Men. The following Figure 1 shows the Gender Development Index or GDI trend in Indonesia during 2011 to 2017: 


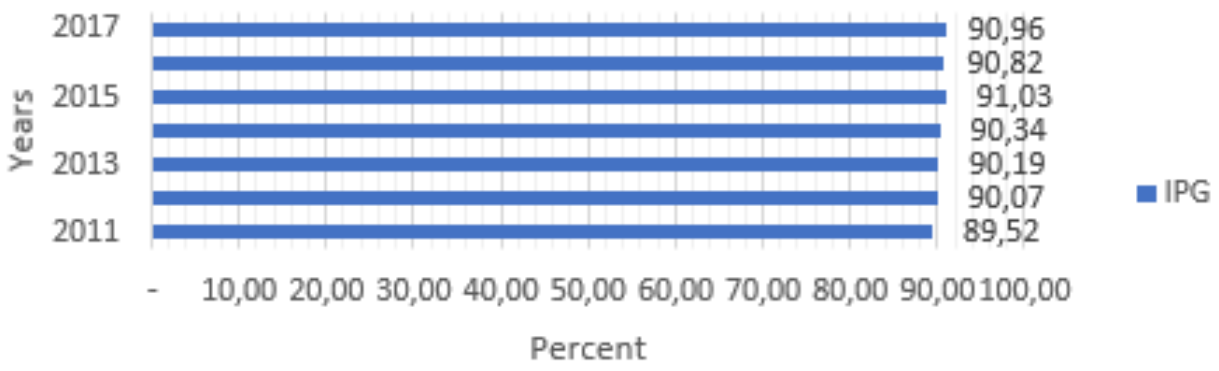

Figure 1. Development Trend of Gender Development Index (GDI) in Indonesia 2011-2017 Source: BPS, 2019

Based on Figure 1, human development for both men and women in Indonesia in the last 7 years has increased. The center of the national economy is on the island of Java. According to BPS (2019), Java Island is still dominant in terms of contribution to the Gross National Product compared to other islands. In 2019, Java Island contributed 59 percent to the Indonesian economy with a growth of 5,52 percent (BPS, 2020). The following Table 1 shows the Gender Development Index or GDI, the Human Development Index or HDI for Men, the Human Development Index or HDI for Women and Ranking of the Gender Development Index or GDI in Jawa Island 2018:

Table 1. GDI, HDI for Men, HDI for Women and GDI Ranking in Java Island in 2018

\begin{tabular}{ccccc}
\hline Province & GDI (\%) & $\begin{array}{c}\text { HDI } \\
\text { For Men (\%) }\end{array}$ & $\begin{array}{c}\text { HDI } \\
\text { For Women (\%) }\end{array}$ & $\begin{array}{c}\text { Ranking of } \\
\text { GDI }\end{array}$ \\
\hline DI Yogyakarta & 94,73 & 82,34 & 78,00 & 1 \\
DKI Jakarta & 94,70 & 83,28 & 78,87 & 2 \\
Jawa Tengah & 91,95 & 75,13 & 69,08 & 3 \\
Banten & 91,30 & 76,22 & 69,59 & 4 \\
Jawa Timur & 90,77 & 75,27 & 68,32 & 5 \\
Jawa Barat & 89,19 & 75,49 & 67,33 & 6 \\
\hline
\end{tabular}

Source: KPPPA, 2019

Based on Table 1, can be seen the Gender Development Index or IPG for Java Island has varies. The highest The Gender Development Index o IPG in Java Island is on Special Region of Yogyakarta where in The Gender Development Index or IPG score as big as 94,73 percent. Special Region of Yogyakarta is also one of the provinces in Indonesia that has the highest IPG score at the national level, get two top ranking nationally in 2018 with score that exceeds the national IPG score in 2018 as big as 90,99 percent.

IPG score is big as 94.73 percent shows the Gender Development Indeks or IPG in Special Region of Yogyakarta is better than other provinces. In addition, the achievement of this high IPG is used as an illustration of the efforts and efforts of the local government in realizing gender equality in the Province of D.I. Yogyakarta (KPPPA, 2019). According to Arfiani and Lisyaningsih (2011), the number of gender-based policies issued affect the high achievement of the IPG in D.I. Yogyakarta Province. In addition, the Regional Governments of D.I. Yogyakarta Province continues to strive in realizing the ideals of INPRES RI No. 9 of 2000 on gender mainstreaming. The following Table 2 shows GDI, HDI for men and HDI for women in the Province of D.I. Yogyakarta 2017-2018. 
Table 2. IPG, HDI for men and HDI for women in the Province of D.I. Yogyakarta 2017-2018

\begin{tabular}{|c|c|c|c|c|c|c|c|}
\hline \multirow{2}{*}{ No } & \multirow{2}{*}{ District/City } & \multicolumn{2}{|c|}{ GDI } & \multicolumn{2}{|c|}{ HDI For Men } & \multicolumn{2}{|c|}{ HDI For Women } \\
\hline & & 2017 & 2018 & 2017 & 2018 & 2017 & 2018 \\
\hline 1 & Kulon Progo & 94,93 & 95,03 & 76,74 & 77,24 & 72,85 & 73,40 \\
\hline 2 & Bantul & 94,98 & 95,11 & 81,31 & 82,04 & 77,23 & 78,03 \\
\hline 3 & Gunungkidul & 84,03 & 84,59 & 75,15 & 75,48 & 63,15 & 63,85 \\
\hline 4 & Sleman & 95,62 & 96,01 & 84,62 & 85,15 & 80,91 & 81,75 \\
\hline 5 & Kota Yogyakarta & 98,26 & 98,48 & 86,21 & 86,71 & 84,71 & 85,39 \\
\hline \multicolumn{2}{|c|}{ D.I.Yogyakarta } & 94,39 & 94,73 & 81,77 & 82,34 & 77,18 & 78,00 \\
\hline
\end{tabular}

Based on Table 2, it can be seen that the gender development indeks or IPG, the human development indeks or IPM for men and women in D.I. Yogyakarta has increased annually in both the district/city and province levels. However, there is still a gap between IPM for men and IPM for women in the province and district/city where IPM score for meni s higher then IPM score for women. This suggest that there is still a gap of development men and women in Special Region of Yogyakarta.

The success of human development can be seen how the big of development problems can be solved. Act as an executive in the system, government, as well as, local government, use policies such as fiscal policy in order to achieve the development target by spending its funds into particular sectors. and can be called government spending (Sukirno, 2004).

In the context of achieving sustainable development on the region, some sectors such as education and health sectors has been identified by local government of D. I Yogyakarta as sectors that affect the human development. The following Table 3 shows local government expenditures in Province of D.I. Yogyakarta according to development sectors function.

Table 3. Realization of Local Government Expenditures by Development Function in D.I. Yogyakarta Province in 2017 (000 Rp)

\begin{tabular}{clcc}
\hline No. & Expenditure Details & Value $(000 \mathrm{Rp})$ & Realization of Allocation (\%) \\
\hline 1 & Public Service & 490.112 .031 & 19,76 \\
2 & Education & 404.645 .471 & 16,31 \\
3 & Tourism and Culture & 400.902 .389 & 16,16 \\
4 & Environment & 359.991 .156 & 14,51 \\
5 & Housing and Public & 254.413 .810 & 10,26 \\
& Facilities & & \\
6 & Health & 253.791 .865 & 10,23 \\
7 & Economy & 243.607 .461 & 9,82 \\
8 & Social Protection & 43.136 .409 & 1,74 \\
9 & Order and Security & 30.244 .554 & 1,22 \\
\hline & Sum of Expenditure & 2.480 .845 .146 & 100,00 \\
\hline
\end{tabular}

Source: BPS, 2018

Based on Table 3, Local Government D.I. Yogyakarta spends its budget on education with a percentage of 16,31 percent of the total expenditure. In the health sector, Local Government D.I. Yogyakarta spends 2,82 percent of the total expenditure budget.

On the other hand, an regional economy also affect the achievement of human development where a good economy can increase economic growth. The economic growth of region can be seen from the growth of the Gross Domestic Regional Product (PDRB) that shows the development of regional economy annually (BPS, 2019). The following Table 4 shows the Gross Domestic Regional 
Product or PDRB and growth rate of PDRB in D.I. Yogyakarta Province at constant prices by district or city in 2013-2017:

Table 4. Gross Domestic Regional Product of D.I. Yogyakarta Province on the basis of constant prices and growth rates in 2013-2018

\begin{tabular}{ccc}
\hline Years & $\begin{array}{c}\text { PDRB on the basis of constant } \\
\text { prices (Billion Rupiah) }\end{array}$ & Growth Rates of PDRB (\%) \\
\hline 2013 & 75.627 & - \\
2014 & 79.536 & 5,17 \\
2015 & 83.474 & 4,95 \\
2016 & 87.686 & 5,05 \\
2017 & 92.302 & 5,26 \\
2018 & 98.027 & 6,20 \\
\hline
\end{tabular}

Source: BPS, 2018

Based on Table 4, Gross Domestic Regional Product or PDRB in D.I. Yogyakarta Province from year after year has been raised with the highest achievement has record of IDR 98,021 billion rupiah in 2018. But as far as growth is concerned, the rate of growth has fluctuated with the highest rate of 6.20 percent in year 2018.

In this study, researchers will use the dependent variable of Gender Development Index and will be carried out in D.I. Yogyakarta Province, is rarely used in previous research because previous research only discuss human development without difference gender. Additionally, the study will be carried out due to a phenomenom for the human develompent of gender based at the district or city level in D.I. Yogyakarta Province and gender is an issue thats ben talked about all over the world. The Previous research such as research from Arifin et al (2016), Gopalakrishna et al (2012), Firmansyah et al (2020) and Baeti (2013) discusses the effect of government spending on education, government spending on health and economic growth on the human development index, and however the reasearch on their effect on the Gender Development Index is still absent. So the researchers are interested to study in the factors affecting the gender development index in the Special Region of Yogyakarta.

This research aims to analyze the affect of government spending on education, government spending on health and economic growth to Gender Development Index in D. I Yogyakarta Province. This research also wants to know which sectors among government spending variables that has most influential effect on Gender Development Index in D. I Yogyakarta Province.

\section{METHODS}

The method used in this research is quantitative descriptive method. In this study, the Gender Development Index in the Province of D.I. Yogyakarta is the dependent variable. While the independent variable consists of government expenditure in the education sector, government expenditure in the health sector, economic growth in the Province of D.I. Yogyakarta. The object of this research is government expenditure in the education sector, government expenditure in the health sector, economic growth of the Regency/City in the Province of D.I. Yogyakarta in a period of nine years from 2010-2018. This research took place in the Special Region of Yogyakarta Province. This study uses internet access to the official website of the Central Bureau of Statistics (BPS) in D.I. Yogyakarta and other websites that are considered relevant. The observation period for this research will be carried out for one month, which is in 2020. This research uses secondary data which is data that is derived from local government web such as Central Bureau of Statistics (BPS), the Ministry of Women's Empowerment and Child Protection (KPPPA) and the Directorate General of Fiscal Balance (DJPK). The data taken consists of Government Expenditures in the Education Sector, Government Expenditures in the Health Sector, and Economic Growth. This study will use a panel data model with 
the number of cross-sections as many as 5 districts/cities in the Province of Yogyakarta Special Region and the number of time series as many as 9 years in 2010 until2018.

To find out how the factors supposedly affected the Gender Development Indeks in D.I. Yogyakarta Province would then be analyzed using the regression panel data model. According to Gujarati (2010), panel data is a combination of time series and cross section. The advantage of uses regression panel data is that panel data provides more data to be prepared make greater degree of fredom, and data panel are the solution to problems that arise in the variable omission (Widarjono, 2009). Regression panel data uses because of the development gap between different men and women in each district/city in D.I. Yogyakarta Province. The regression panel data equation this study can be avowed in the following form of functions:

$$
I P G_{i t}=\beta_{0}+\beta_{1} L n P P P_{1 i t}+\beta_{2} L n P P K_{2 i t}+\beta_{3} P E_{3 i t}+e_{i t}
$$

Where :

$\begin{array}{ll}\text { IPG } & : \text { Gender Development Index (percent) } \\ \beta 0 & : \text { Constant } \\ \beta 1, \beta 2, \beta 3 & : \text { Regression coefficient } \\ \text { LnPPP } & : \text { Government expenditure on education (rupiah) } \\ \text { LnPPK } & : \text { Government Expenditure on health (rupiah) } \\ \text { PE } & : \text { Economic growth (percent) } \\ \text { I } & : \text { Time Series (Year) } \\ \text { T } & : \text { Cross Section (Regency / City) } \\ \text { e } & : \text { Error Term }\end{array}$

In panel data regression analysis, there are three model choices that match the characteristics of the data so the estimator result are not biased. Three model choices are identified as follows: 1) Chow test, which is to choose the best model between the common effect model (CEM) or the fixed effects model (FEM). 2) Hausman test to choose which model is better to use between random effects model (REM) or fixed effects model (FEM) (Ghozali and Ratmono, 2013). 3) Langrane Multiplier (LM) test to select and better determine which random effects model (REM) and common effect model (CEM) should be used (Ghozali and Ratmono, 2013). According to Gujarati (2013) the classic assumption test is used so that the model is not biased or meets BLUE (Best Linear Unisex Estimator), namely the normality test, multicollinearity test, heteroscedasticity test and autocorrelation test. Furthermore, a statistical test consisting of a partial test, simultaneous test and determination test. Furthermore, an elasticity test is carried out to determine which the local government spending variable that has the most influence effect on the gender development index.

\section{RESULTS AND DISCUSSIONS}

The affect of government spending on education, government spending on health, and economic growth on the Gender Development Index in D.I. Yogyakarta tested uses chow test and hausmand test. Based on the results of the Chow test and the Hausman test, the appropriate panel data regression model to be used in data estimation is the fixed effects model (FEM). The results of panel data regression with a fixed effect model (FEM) are as follows:

Table 5. Panel Data Regression Results for Fixed Effects Models

\begin{tabular}{ccccc}
\hline Variable & Coefficient & Std. Error & t-Statistic & Prob. \\
\hline C & 94,52093 & 2,801100 & 33,74421 & 0,0000 \\
LNPPP & $-0,599516$ & 0,185968 & $-3,223770$ & 0,0026 \\
\hline LNPPK & 0,491155 & 0,188464 & 2,606090 & 0,0131 \\
PE & 0,346382 & 0,125210 & 2,766402 & 0,0088 \\
\hline
\end{tabular}

F-statistic : 285,70

Prob. F-stat : 0,00

Adjusted R-square : 0,978399

Source: processed data, 2020 
Based on Table 5, regression equation can be written as follows:

$Y=94,5209-0,5995$ LnPPPit $+0,4912$ LnPPKit $+0,3464$ PEit

The results of the regression analysis show that the coefficient value of government expenditure on education variable is -0,5995 which is interpreted as if there is an increase in government expenditure on education by one percent it will cause a decrease in the gender development indeks in D.I. Yogyakarta by 0,5995 percent. The result of the regression data panel is not consistent match with the hypothesis that have been formulated that government expenditure on education has a positive and significant effect. But the results of this study are consistent with research from Nor and Nasrudin (2019) and Laode et al (2020).

We argue that because government expenditure on education is aimed at the general public regardless of existing gender. The realization of government expenditure on education is more enjoyed by the male gender than the female gender. This is related to the gender and cultural stereotypes that exist in the people of D.I. Yogyakarta, where the male gender is considered the breadwinner and is dominant in the public sector with women being considered as caretakers of the house and dominant in the domestic sector.

The results of the regression analysis show that the coefficient value of government expenditure in the health sector is 0,4912, meaning that if there is an increase in government expenditure on health by one percent, it will cause an increase in the gender development index in D.I. Yogyakarta by 0,4912 percent. This is in accordance with the hypothesis which states that government spending on health has a positive and significant effect on the gender development index in D.I. Yogyakarta. The results of this study are in line with research from Arifin et al (2015), Baeti (2013) and Mahulauw et al (2016). This can occur because government spending on health can improve the level of public health so that healthy humans can live longer and work better than unhealthy humans.

The results of the regression analysis show that the coefficient of economic growth has a value of 0,3463 , meaning that if there is an increase in economic growth of one percent, it will cause an increase in the gender development index D.I. Yogyakarta by 0,3464 percent. This is in accordance with the hypothesis which states that economic growth has a positive and significant effect on the gender development index D.I. Yogyakarta. The results of this study are in line with research from Baeti (2013), Agustina et al (2016), Firmansyah et al (2020) and Bundala (2012). This can occur because an increase in economic growth will increase the level of labor productivity and the level of labor force participation in the economy, thereby increasing the quality of human resources and the welfare of society.

Because the model used in this study is a fixed effects model (FEM) which assumes that there are differences in the intercept between individuals. The difference in interpersonal interpretation shows that each individual in this study, namely each district/city has a different gender development index. The following is the intercept data between districts/cities in the Province of D.I. Yogyakarta:

Table 6. Intercept of District/City in the Province of D.I. Yogyakarta

\begin{tabular}{ccc}
\hline No. & District/City & Effect \\
\hline 1 & Bantul & 1,340794 \\
2 & Gunung Kidul & $-9,937624$ \\
3 & Kulon Progo & 1,011493 \\
4 & Sleman & 2,127789 \\
5 & Yogyakarta & 5,457548 \\
\hline
\end{tabular}

Source: processed data, 2020

The F-statistic value is 285,70 which is greater than 3,22 ( $F$ table value), which means that together all the independent variables, namely government expenditure on education, government expenditure on health and economic growth affect the gender development index in D.I. Yogyakarta.

Value of adjusted $R^{2}$ is 0,9784 or it means that the gender development index variable can be explained by the variable government spending on education, government spending on health and 
economic growth by 97,84 percent. And the remaining 2,16 percent of the gender development index variable is explained by other variables.

The most influence independent variable on the gender development index in D.I. Yogyakarta Province are obtained through elasticity test.

Table 7. Elasticity Test

\begin{tabular}{cc}
\hline Variable & Coefficient \\
\hline LNPPP & $-0,599516$ \\
LNPPK & 0,491155 \\
PE & 0,346382 \\
\hline
\end{tabular}

Source: processed data, 2020

The government expenditure variable in the health sector has the largest beta coefficient of 0,4912 compared to other independent variables so that government expenditure on health is the variable that has the greatest affect on the Gender Development Index D.I. Yogyakarta from 2010 to 2018. Health plays an important role in human development because with good level of health make the better of ability and quality, whereas if the health are bad then the ability and quality is worse. Life expectancy D.I. Yogyakarta is higher than National Life Expectancy, indicating that the management of government expenditure specifically in the health sector is successful. This is due to the improvement in quality and health services, improvement in community nutrition and a decrease in the annual mortality rate. The results of this study are in accordance with the formulation of the research hypothesis, namely that the most influential variable is government expenditure on health. This result is consistent with previous research that is research of Arifin et al. (2015) and Firmansyah et al. (2020).

\section{CONCLUSION}

Based on the results obtained from processing research data on the analysis of factors affecting the gender development index in DI Yogyakarta Province, the conclusions that can be drawn are as follows: Government Expenditure Variables in Education have a negative and significant effect on the Gender Development Index in DI Yogyakarta Province, The Government Expenditure Variable in the Health Sector has a positive and significant effect on the Gender Development Index in DI Yogyakarta Province. The Economic Growth Variable has a positive and significant effect on the Gender Development Index in the DI Yogyakarta Province. The independent variable that has the greatest influence on the Gender Development Index D.I. Yogyakarta is a variable of government spending on health. Based on the results obtained from the processing of research data and the conclusions that have been drawn, several implications can be compiled as follows: Government expenditure in education has a negative effect on Gender Development Index (IPG) so it is hoped that both the Provincial and District/City Governments in D.I. Yogyakarta to pay more attention to the ability of each region in realizing the education budget according to what has been determined so that the results obtained can be maximized. In addition, there needs to be a strengthening of cooperation and alignment of missions between the Provincial and Regency / City Governments in D.I. Yogyakarta to optimize government performance. Equitable education is needed to reduce the education gap that occurs between urban and rural areas in D.I. Yogyakarta can provide proper facilities and infrastructure, improve infrastructure such as repairing school facilities and buildings, repairing inadequate public transportation, providing school assistance specifically for the underprivileged as well as for high achievers, revamping the existing education system and facilities in accessing education, especially for the low-income population; Government expenditure in the health sector has a positive effect on Gender Development Index (IPG) and is the variable that has the largest beta coefficient compared to other independent variables, so the government should increase the percentage of budget allocation for the health sector provided that there is a minimum of 10 percent of the APBD, both provincial and district/city. In addition, it is necessary to optimize performance in financial management so that the health budget can be optimally realized as well. Increasing the 
special health budget and allocating according to a predetermined percentage is expected to improve the quality of health in D.I. Yogyakarta through the improvement of health facilities such as the construction of existing hospitals, clinics, health centers and or by increasing the number of health infrastructure. In addition, it is easy to access health, especially for the less fortunate with health assistance such as free medical treatment so that all levels can get good health facilities.; Economic growth has a positive effect on Gender Development Index (IPG), therefore the government should make efforts to equalize the economic growth of each district / city so that the results can be enjoyed by all levels of society. In addition, increasing economic growth also needs to be considered through the achievement of PDRB which will eventually lead to a better regional economy. With equal distribution and increased economic growth, it is hoped that it can drive economic activities in the regions and increase regional productivity so that the availability of employment opportunities will increase in line with the increase in the quality of human resources.

\section{Research Limitations}

The limitation in this study is the use of research data which is limited in the period and area of observation so that the research data used is also limited and is less able to explain and describe the actual situation in the research location. Information about each variable used as well as research data tends to be incomplete and difficult to find and research on the gender development index is still very little so that in this study researchers are not able to explain and explain well. Therefore, further research is expected to complement the existing shortcomings so that it can better explain the gender development index in the Province of D.I. Yogyakarta is better than previous studies.

\section{REFERENCES}

Agustina, E., Rochaida, E., \& Ulfah, Y. (2016). Pengaruh Pengeluaran Pemerintah Daerah Sektor Pendidikan dan Kesehatan Terhadap Produk Domestik Regional Bruto serta Indeks Pembangunan Manusia di Kalimantan Timur. Jurnal Ekonomi Keuangan, Vol 2, (2), 192-217. https://journal.feb.unmul.ac.id/.

Arfiani, G., \& Lisyaningsih, U. (2013). Disparitas Spasial Indeks Pembangunan Gender Daerah Istimewa Yogyakarta Tahun 2010. Jurnal Bumi Indonesia, 2 (4).

Arifin, M. Y., Suswandi, P. E., \& Adenan, M. (2015). Pengaruh Pengeluaran Pemerintah Sektor Kesehatan, Pengeluaran Pemerintah Sektor Pendidikan dan Pertumbuhan Ekonomi terhadap Indeks Pembangunan Manusia Jawa Timur 2006-2013. Artikel Ilmiah Mahasiswa, 1-8. https://repository.unej.ac.id/.

Badan Pusat Statistik. (2019). Daerah Istimewa Yogyakarta Dalam Angka 2017-2019. Yogyakarta: Badan Pusat Statistik.

Badan Pusat Statistik. (2018). Indeks Pembangunan Manusia 2014 dan 2018. Jakarta: Badan Pusat Statistik.

Badan Pusat Statistik. (2019). Produk Domestik Regional Bruto Kabupaten/Kota Di Indonesia 20102018. Jakarta: Badan Pusat Statistik

Baeti, N. (2013). Pengaruh Pengangguran, Pertumbuhan Ekonomi, dan Pengeluaran Pemerintah terhadap Pembangunan Manusia Kabupaten/Kota di Provinsi Jawa Tengah Tahun 2007-2011. Economics Development Analysis Journal (EDAJ), Vol 2, No. 3, 85-98. DOI: https://doi.org/10.15294/edaj.v2i3.1984.

BAPPEDA DIY. (2015). Laporan Kinerja (LKj) Pemerintah Daerah Daerah Istimewa Yogyakarta (Pemda DIY) Tahun 2015. Yogyakarta: Pemda DIY.

Bundala, N. (2012). Economic Growth and Human Development: A Link Mechanism: An Empirical Approach. Munich Personal RePEc Archive, No. 47648. https://mpra.ub.unimuenchen.de/47648/.

Direktorat Jenderal Perimbangan Keuangan. 2014. Anggaran Belanja per Fungsi 2014. Diakses pada 20 Agustus 2020 https://djpk.kemenkeu.go.id/setelah-ta-2006/

Firmansyah, R., Ilman A.H., \& Cita F.P. (2020). Pengaruh Pengeluaran Pemerintah dan Pertumbuhan Ekonomi Terhadap Indeks Pembangunan Manusia di Kabupaten Sumbawa tahun 2004-2017. 
Nusantara Journal of Economics (NJE), Vol 2, $\quad$ No. 01 pp 53-62. https://doi.org/10.37673/nje.v2i1.661

Ghozali, I. (2006). Aplikasi Analisis Multivariate dengan Program SPSS (Edisi Ke-4). Semarang: Badan Penerbit Universitas Diponegoro.

Ghozali, I., \& Ratmono, D. (2013). Analisis Multivariat dan Ekonometrika : Teori, Konsep dan Aplikasi dengan E-views 8. Semarang: Badan Penerbit Universitas Diponegoro.

Gopalakrishna, B. V., \& Rao, J. (2012). Economic Growth \& Human Development: The Experience of Indian States. The Indian Journal of Industrial Relations, 634-644. https://www.jstor.org/stable/23267365.

Gujarati, D. N. (2010). Dasar-Dasar Ekonometrika Buku Dua. Jakarta: Salemba Empat.

Kementerian Pemberdayaan Perempuan dan Perlindungan Anak. (2019). Pembangunan Manusia Berbasis Gender 2011-2019. Jakarta: Kementerian Pemberdayaan Perempuan dan Perlindungan Anak.

Laode, M., Engka, D. S., \& Sumual, J. I. (2020). Analisis Pengaruh Pertumbuhan Ekonomi, Kemiskinan dan Pengeluaran Pemerintah Sektor Pendidikan terhadap Indeks Pembangunan Manusia di Provinsi Sulawesi Utara (2015-2018). Jurnal Berkala Ilmiah Efisiensi, Volume 20 No. 02.

Mahulauw, A. K., Santosa, D. B., \& P. M. (2016). Pengaruh Pengeluaran Kesehatan dan Pendidikan serta Infrastruktur terhadap Indeks Pembangunan Manusia di Provinsi Maluku. Jurnal Ekonomi Pembangunan, Vol 14, No. 02, 122-148. DOI: https://doi.org/10.22219/jep.v14i2.3850.

Mangkoesoebroto, G. (2001). Ekonomi Publik, Edisi-III. Yogyakarta: BPFE-Yogyakarta.

Nachrowi, D. Nachrowi \& Hardius Usman (2006). Pendekatan Populer dan Praktis Ekonometrika Untuk Analisis Ekonomi dan Keuangan. Jakarta: Lembaga Penerbit Fakultas Ekonomi Universitas Indonesia.

Nor*, Muhammad, \& Nasruddin. (2019). Analisis Pengaruh Pengeluaran Pemerintah di Sektor Pendidikan dan Kesehatan terhadap Indeks Pembangunan Manusia Provinsi Kalimantan Selatan. Jurnal IImu Ekonomi dan Pembangunan (JIEP), Vol. 2 No. 1, hal 33-45.

Peraturan Menteri Dalam Negeri Republik Indonesia Nomor 67 Tahun 2011 tentang Perubahan Atas Peraturan Menteri Dalam Negeri Nomor 15 Tahun 2008 tentang Pedoman Umum Pelaksanaan Pengarusutamaan Gender Di Daerah (2011).

Sukirno, S. (2004). Makroekonomi. Jakarta: PT. Rajagrafindo Persada.

Undang-Undang Dasar 1945 pasal 31 ayat 4 tentang Perubahan Pengaturan Sistem Anggaran Pendidikan Sebesar 20 persen dari APBN dan atau APBD (2002)

Undang-Undang Nomor 27 Tahun 2014 tentang Anggaran Pendapatan dan Belanja Negara Tahun Anggaran 2015 (2014).

Undang-Undang Nomor 36 Tahun 2009 tentang Kesehatan (2009).

Widarjono, A. (2009). Ekonometrika Pengantar dan Aplikasinya, Edisi Ketiga. Yogyakarta: Ekonisia. 